\title{
SEROVAR PROFILE AND DETECTION OF INVA VIRULENCE GENE AMONG NON-TYPHOIDAL SALMONELLAE SEROVARS ISOLATED FROM ACUTE GASTROENTERITIS CASES IN COASTAL KARNATAKA, SOUTHERN INDIA
}

\author{
SOHAN BANGERA ${ }^{1}$, SHASHIKIRAN UMAKANTH ${ }^{2,3}$, RAM BHAT ${ }^{4}$, ASHA KAMATH ${ }^{5}$, MAMATHA BALLAL ${ }^{6}$, \\ Asish Kumar Mukhopadhyay ${ }^{7}$
}

\begin{abstract}
${ }^{1}$ Department of Microbiology, Enteric Diseases Division, Kasturba Medical College, Manipal University, Manipal, Karnataka, India. ${ }^{2}$ Department of Medicine, Melaka Manipal Medical College, Manipal University, Manipal, Karnataka, India. ${ }^{3}$ Department of Medicine, Dr. TMA Pai Hospital, Udupi, Karnataka, India. ${ }^{4}$ Department of Medicine, Kasturba Medical College, Manipal University, Manipal, Karnataka, India. ${ }^{5}$ Department of Community Medicine, Kasturba Medical College, Manipal University, Manipal, Karnataka, India. ${ }^{6}$ Department of Microbiology, Enteric Diseases Division, Kasturba Medical College, Manipal University, Manipal, Karnataka, India, ${ }^{7}$ Scientist E, Bacteriology Division, National Institute of Cholera and Enteric Diseases (NICED), Kolkata, India. Email: mamatha.ballal@manipal.edu, mamatha.ballal08@gmail.com, asish1967@gmail.com
\end{abstract}

Received: 05 May 2017, Received and Accepted: 22 September 2017

ABSTRACT

Objective: Non-typhoidal salmonellosis is one of the leading zoonosis in the world caused by non-typhoidal Salmonella (NTS). Invasive infections with NTS serovars occurs due to the presence of virulence genes like invA along with the immunosuppressive conditions of the patient. The study was conducted to isolate and identify the NTS serovars and their antimicrobial resistance profile from patients with diarrhea and also to detect the virulence marker - invA gene among these NTS serovars.

Methods: A prospective cross-sectional study was conducted from January 2015 to December 2016 at the Enteric Diseases Division, Kasturba Medical College, Manipal. 1218 fecal specimens were collected from patients with diarrhea and before antibiotic treatment. NTS serovars were identified, serotyped and then screened for the presence of invA virulence gene.

Results: A total of 33 (2.7\%) NTS was isolated. Salmonella typhimurium (33.34\%) was predominant followed by Salmonella oslo (30.3\%). Out of 33 NTS, invA was positive for 28 isolates (84.8\%) of which 25 (89.3\%) patients were febrile which was statistically significant (p=0.000).

Conclusion: Non-typhoidal salmonellosis is an emerging global infection among immunocompromised patients. Our study showed an association between the invA gene and febrile illness among the patients suffering. Thus, this study highlights the importance of invA as a significant marker for bloodstream invasion.

Keywords: Non-typhoidal salmonellosis, invA gene, Virulence, Non-typhoidal Salmonella, Bloodstream infection.

(C) 2018 The Authors. Published by Innovare Academic Sciences Pvt Ltd. This is an open access article under the CC BY license (http://creativecommons. org/licenses/by/4. 0/) DOI: http://dx.doi.org/10.22159/ajpcr.2018.v11i1.21839

\section{INTRODUCTION}

Non-typhoidal salmonellosis is one among the leading causes of zoonosis and gastrointestinal infection in the world [1]. It defines the disorders produced by all serotypes of Salmonella, excluding typhi and paratyphi group [2]. The prominent non-typhoidal Salmonella (NTS) causing salmonellosis are Salmonella gallinarum, Salmonella typhimurium, Salmonella choleraesuis, Salmonella enteritidis, Salmonella dublin, and Salmonella abortusovis [3]. Human beings acquire this infection through the consumption of undercooked, uncooked, contaminated food such as eggs, chicken meat, pork, beef, and unpasteurized milk [4]. The clinical manifestations start with an infectious diarrhea that begins within 12-72 $h$ after the intake of infected food [1]. The affected person shows symptoms of diarrhea, vomiting, and abdominal pain [1]. There is a possibility that these non-typhoidal Salmonella (NTS) serovars with their diverse invasive virulence genes can cause invasive non-typhoidal salmonellosis resulting in bloodstream infection among adolescents with comorbid conditions such as malaria, malnutrition, and in adults with HIV [5-7]. The clinical manifestation of invasive non-typhoidal salmonellosis is typically a febrile systemic illness which simulates to that of enteric fever, diarrhea is usually not present, and other clinical symptoms vary and are not defined [8]. Risk factors are found to be HIV infection and its worsening illness, malnutrition [8]and malaria [9]. There are several virulence genes such as invA, spv, sefA, stn, and $\operatorname{sop} B$ that are responsible for its colonization, invasiveness, intracellular survival, and damage to host tissues [10].
The bacteria responsible for Non-typhoidal salmonellosis and its invasiveness vary depending on the population and place $[5,7,9]$. It was observed that no much work has been carried out on this emerging foodborne zoonotic infection from this region of coastal Karnataka. The recent substantial increase in the number of NTS isolates in this part of coastal Karnataka beckons the need for phenotypic and genotypic characterization of the isolates to raise awareness especially regarding their role in foodborne infections. With the growing antimicrobial resistance profile and the severity of invasive cases, we need to have an idea of the likely bacterial serovars and their presumptive antibiotic therapy to improve the outcome of the treatment. The present study was also conducted to detect the invA gene as a marker for bloodstream invasion caused by NTS isolated from this region.

\section{METHODS}

Fecal specimen of patients suffering from acute gastroenteritis or dysentery admitted to the wards and presenting at the outpatient departments were collected and transported to the Enteric Diseases Division, Kasturba Medical College, Manipal, for a period of 2 years (January 2015 - December 2016).

The study was submitted and approved by the Institutional Ethics Committee. Following the informed consent from patients with diarrhea, a standard clinical questionnaire was completed. The patient's 
demographic details were collected and recorded, and it consisted of clinical data (presence of fever, abdominal pain, and vomiting), underlying conditions, physical and systemic examinations, date of the diarrheal episode, frequency of diarrhea, history of travel, type of food consumed and laboratory investigations.

\section{Isolation and identification of NTS from fecal samples}

The samples were collected in sterile wide mouthed container following aseptic precautions and immediately transported for further processing according to the protocol given by centers for disease control and prevention (CDC) [11]. Primary inoculation was carried out on MacConkey's agar (HiMedia Laboratories) and Hektoen Enteric agar (Difco, BD), and enrichment was performed on Selenite Feces broth (HiMedia Laboratories) which was subcultured after overnight incubation. Non-lactose fermenting colonies from MacConkey agar plates and green with black centered colonies from Hektoen Enteric agar plates were picked and subjected to further analysis for biochemical tests for the identification of NTS [12].

\section{Antigenic profiling}

Isolates of Salmonella were serotyped with specific polyvalent $\mathrm{O}$ and $\mathrm{H}$ antisera (Remel Diagnostics, Fisher Scientific). The strains confirmed as Salmonella enterica subspecies enterica was further serovar identified and its antigenic profiling was done at the national reference center - National Institute of Cholera and Enteric Diseases, Kolkata, India.

\section{Antimicrobial susceptibility test}

NTS isolated were subjected to antimicrobial susceptibility testing for various antimicrobials, namely, amikacin $(30 \mu \mathrm{g})$, ampicillin $(10 \mu \mathrm{g})$, amoxyclav $(30 \mu \mathrm{g})$, azithromycin $(15 \mu \mathrm{g})$, ceftazidime $(30 \mu \mathrm{g})$, ceftriaxone $(30 \mu \mathrm{g})$, cefuroxime $(30 \mu \mathrm{g})$, chloramphenicol $(30 \mu \mathrm{g})$, ciprofloxacin $(5 \mu \mathrm{g})$, and co-trimoxazole $(25 \mu \mathrm{g})$. Escherichia coli 25922 was used as the control strain. The antimicrobial susceptibility testing was performed by modified Kirby-Bauer's disk diffusion method according to Clinical Laboratory Standards Institute guidelines [13].

Detection of virulence-specific marker - invA gene of NTS

Salmonella enterica serotype (4,5,12:i:-) was used as the positive control and NTS ( $\mathrm{n}=33$ ) genomic DNA were extracted using the protocol as per De Medici et al. [14]. The extracted DNA was quantified using Nanodrop (Eppendorf BioPhotometer D30) with absorbance values at $320 \mathrm{~nm}$. The primer for invA gene was designed using the primer 3 output sequence (available at http://bioinfo.ut.ee/primer3-0.4.0/). The forward primer of invA gene GTTTACGACCTGAATTACTG and reverse primer GATAAGACGACTGGTACTGA with a base pair of 239 was used in this study. The PCR reaction was carried out following Mir et al. [10]. PCR reaction was carried out in a total volume of $12.75 \mu$, consisting of primers ( $0.5 \mu \mathrm{l}$ each), $5 \mathrm{ng}$ of DNA $(1 \mu \mathrm{l})$, Taq polymerase master mix (6.25 $\mu$ l) (Go Green, Promega Corporation, USA), and sterile Milli-Q water was added to make the final volume. The PCR reaction consisted of 1 cycle of an initial denaturation of $94^{\circ} \mathrm{C}$ for $2 \mathrm{~min}$, followed by 35 cycles of $95^{\circ} \mathrm{C}$ for $1 \mathrm{~min}, 57^{\circ} \mathrm{C}$ for $1 \mathrm{~min}$, and $72^{\circ} \mathrm{C}$ for $2 \mathrm{~min}$, and a final extension cycle was performed at $72^{\circ} \mathrm{C}$ for $10 \mathrm{~min}$. The amplified products were analyzed in a $2.5 \%(\mathrm{w} / \mathrm{v})$ agarose gel in $1 \mathrm{X}$ Tris base, acetic acid and EDTA (TAE) buffer. Ethidium bromide (Sigma-Aldrich, USA) $(0.5 \mu \mathrm{g} / \mathrm{mL}$ TAE) stained DNA amplicons were seen using a gel imaging system (Biotron Healthcare)

\section{Statistical analysis}

The software version 16.0 IBM SPSS was used to generate descriptive statistics of data. Chi-square test was used to find out the association of invA gene and febrile illness with $\mathrm{a}{ }^{* *} \mathrm{p}=0.000$.

\section{RESULTS}

Of the total 1218 diarrheal fecal samples collected, 33 isolates were NTS showing a prevalence of $2.7 \%$. S. typhimurium $(33.34 \%, 11 / 33)$ was found to be the most common serovar followed by S. oslo (30.3\%, 10/33). The other NTS isolated are depicted in Fig. 1.

Among the antimicrobial agents screened, resistance was observed in ampicillin and cefuroxime (5/33, 15.1\%), amoxicillin (4/33, 12.1\%), and ciprofloxacin and cotrimoxazole $(3 / 33,9.09 \%)$. Fig. 2 depicts the antimicrobial resistance pattern of NTS isolates.

Out of the 33 NTS screened for invA gene, 28 (84.8\%) isolates were positive for invA gene this is shown in Fig. 3.

Among the 28 invA positives, 25 (89.3\%) of the patients were found to be febrile.

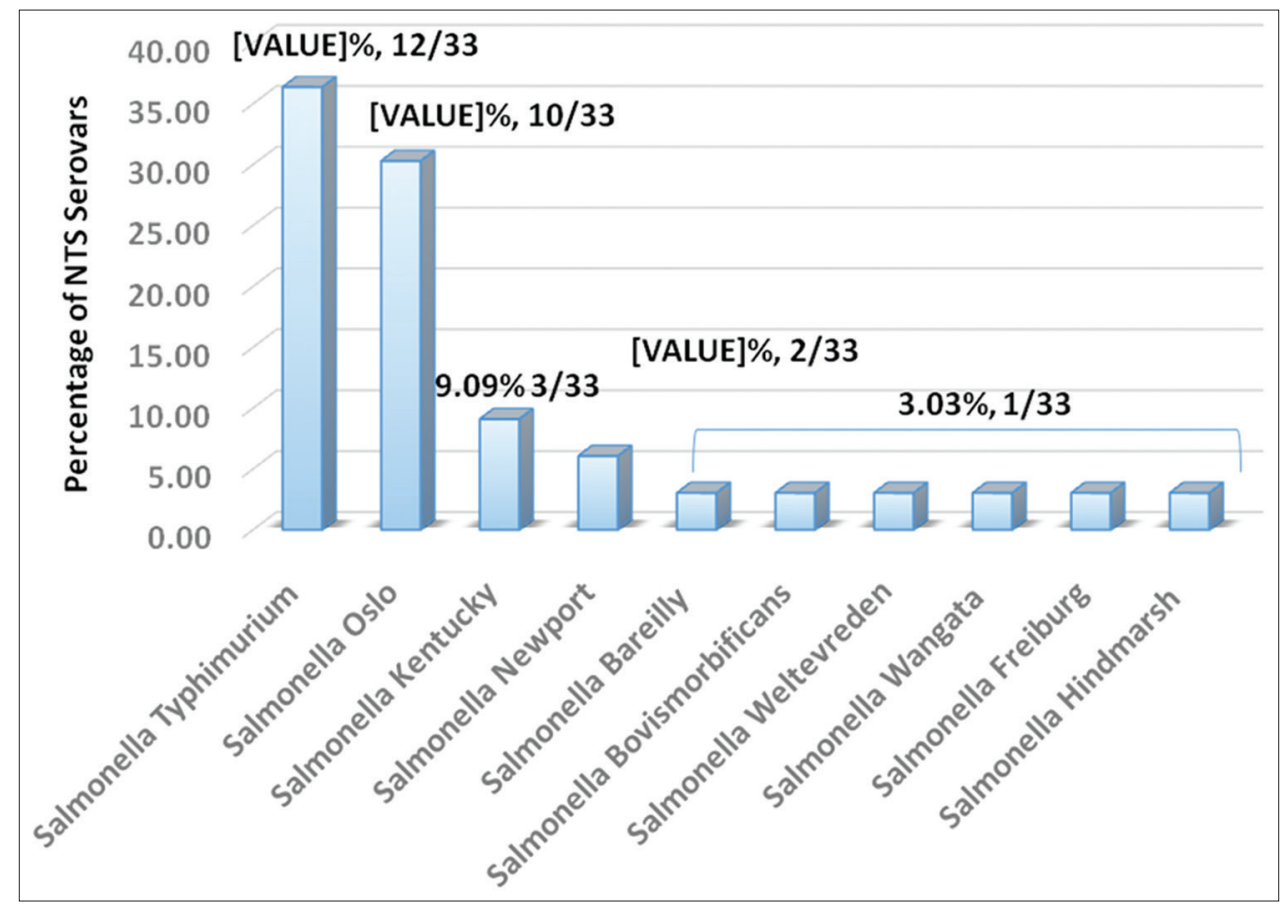

Fig. 1: Non-typhoidal Salmonella serovars causing non-typhoidal salmonellosis 


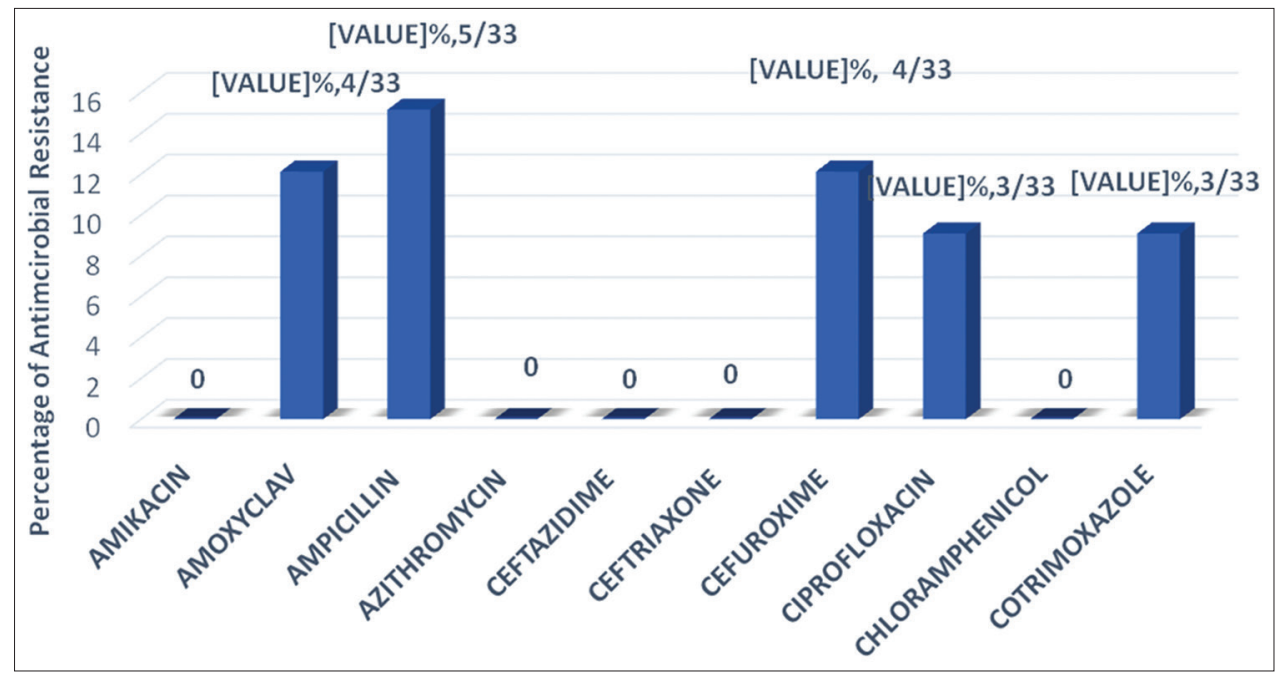

Fig. 2: Antimicrobial resistance pattern of non-typhoidal Salmonella isolates

Table 1: Age distribution of patients with Non-typhoidal salmonellosis

\begin{tabular}{ll}
\hline Age group (years) & Number \\
\hline $11-20$ & 3 \\
$21-30$ & 1 \\
$31-40$ & 3 \\
$41-50$ & 3 \\
$51-60$ & 7 \\
$61-70$ & 14 \\
$71-80$ & 1 \\
$81-90$ & 1 \\
Total & 33 \\
\hline
\end{tabular}

The demographic details were analyzed and the age distribution showed a predominance of patients above 60 years to be infected with salmonellosis. This is depicted in Table 1.

The clinical manifestations associated with non-typhoidal salmonellosis were immunosuppressed conditions illustrated in Fig. 4. All the patients had acute gastroenteritis. The symptoms observed in these patients include fever $(25 / 33,75.8 \%)$, vomiting and abdominal pain $(7 / 33$, $21.21 \%)$, chills $(4 / 33,12.12 \%)$, and headache $(2 / 33,6.06 \%)$.

The most common source of food for non-typhoidal salmonellosis was poultry products $(24 / 33,72.7 \%)$ followed by fruits, vegetables, and water source $(3 / 33,9.09 \%)$, along with dairy products $(2 / 33,6.06 \%)$ and seafood $(1 / 33,3.03 \%)$.

\section{DISCUSSION}

Salmonella serovars invariably have the ability to cause bloodstream infections when they have an assemblage of virulence genes in the Salmonella pathogenicity islands (SPIs)[15]. SPIs have nearly 60 such genes [15]. These SPIs may be located on a bacterial chromosome or large virulence-associated plasmids [16]. Virulence chromosomal genes of NTS are invA, spvC, sefA, sopB, and stn [10]. One such virulence gene is $i n v A$, a local invasion gene essential for the entry of the bacterium from the gut lumen into the epithelial cells [10]. It is the topmost gene of an operon Salmonella [10]. invA gene is a unit of the SPI 1 that is very much required for the complete cell invasion [15]. Our study showed that of the 33 NTS, 28 (84.8\%) isolates were positive for invA gene which is in concordance with the study by Ohud et al. [17] reporting invA gene in $89.9 \%$ of the NTS isolates. However, a West African study by Dione et al. revealed that invA gene was present in $99.5 \%$ of the isolates [18]. Many studies have shown that

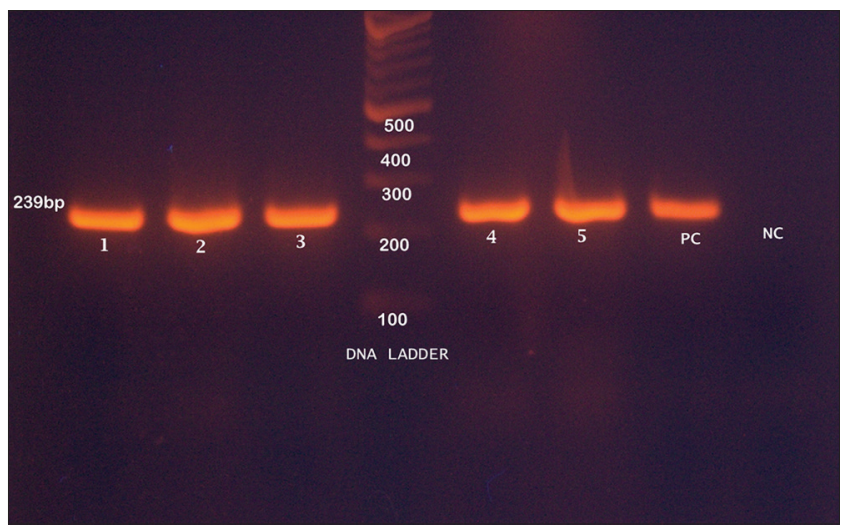

Fig. 3: Gel image showing amplification of invA gene. Bp: Basepair, PC: Positive control, NC: Negative control

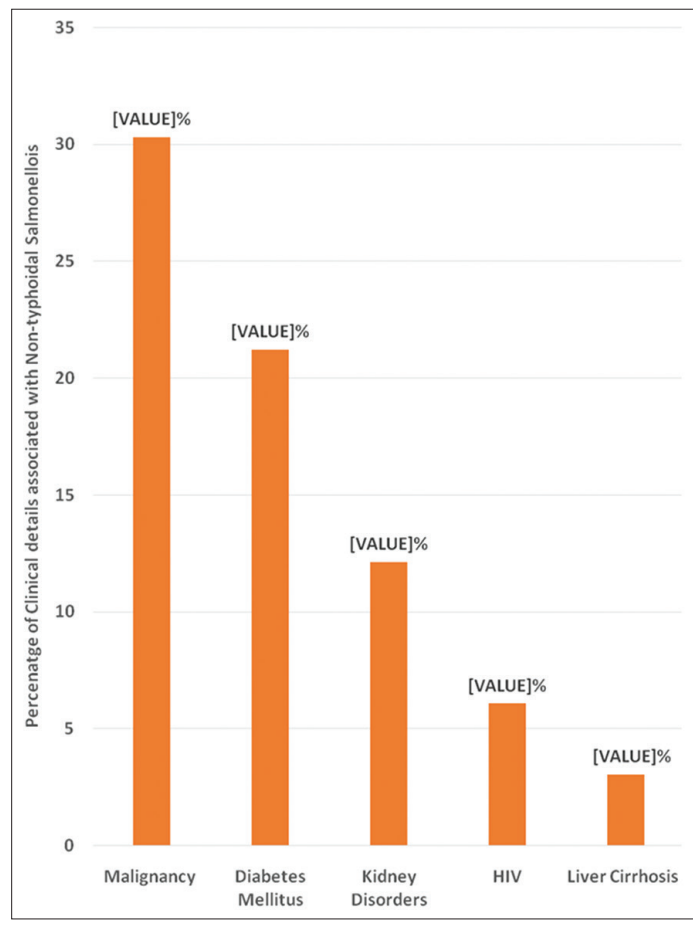

Fig. 4: Clinical details associated with non-typhoidal salmonellosis 
invA gene of NTS carries sequences those of which are distinctive for genus Salmonella; thus invA gene is recognized as an essential target to detect Salmonella by PCR $[19,20]$. The correlation of invA gene with the clinical presentation of fever in patients was found to be significant in this study. Out of the 28 patients with invA gene in their NTS isolate, $25(89.3 \%)$ patients were found to be febrile which was found to be statistically significant $\left({ }^{* *} \mathrm{p}=0.000\right)$. This indicates that invA gene is possibly responsible for the virulence of the bacteria, facilitating their entry into the bloodstream and resultant consequences including fever. Patients negative for invA gene in their NTS serovar did not show any symptom of fever. Thus, there was a good correlation between the invA gene and clinical presentation of fever in patients infected with NTS. Non-typhoidal salmonellosis is recognized as a public health issue in previously normal and healthy individuals causing self-limiting gastroenteritis [21]. Although in immunosuppressed and diseased hosts, NTS can cause invasive infections resulting in bacteremia and sepsis [5]. This is termed as invasive non-typhoidal salmonellosis [5]. Immunosuppressed patients with HIV infection, malignancies, steroid use, kidney disorders, liver cirrhosis, diabetes or sickle-cell disease, infants and aged patients are considered as risk groups for invasive non-typhoidal salmonellosis [22]. The observation in our study was that malignancy $(30.3 \%)$ was the most common immunosuppressed condition followed by acquired immune deficiency syndrome (6.06\%). Other comorbid/risk factors include kidney disorders $(12.12 \%)$ and liver disease (3.03\%). A study in Chandigarh reported non-typhoidal salmonellosis associated with malignancy was $9 \%$ and renal disorders $7 \%$ which is lesser than our study [23]. This finding is similar to a study conducted in Malaysia reporting $23.6 \%$ of malignancy cases; AIDS was $20 \%$, diabetes mellitus, renal disorders and liver cirrhosis were $7.3 \%$ [24]. It was also observed that patients aged above 60 years were diagnosed of NTS and is in concordant with other studies elsewhere $[23,24]$.

Among the serovars isolated, S. typhimurium was the most common serovar followed by Salmonella oslo. Similar findings are being reported by studies in Italy by Frasson et al. [25] and in Africa by Karuiki et al. [26] of $S$. typhimurium being the most frequent serovar causing non-typhoidal salmonellosis. This is in contraindication to studies reported elsewhere in the country. A study conducted by Menezes et al. [27], showed Salmonella agona as the prevalent serovar followed by $S$. typhimurium. Another study by Taneja et al. reported Salmonella senftenberg as the prevailing serovar followed by S. typhimurium [23].

The predominant food source for non-typhoidal salmonellosis was found to be poultry products such as chicken meat and eggs in $72.7 \%$. CDC has reported that a poultry farm in California in 2013 caused about 300 people to be infected with Salmonella heidelberg [28]. NTS generally resides in the gut of poultry, farm animals, and pets. Even the naturally fed poultry can harbor Salmonella [29]. Throughout the time usually NTS does not make the birds and farm animals ill, but they can cause severe disorders when transmitted to humans [29]. Antibiotics are used in poultry for their growth fastening process which results in the colonization of antibiotic resistant bacteria [30]. These resistant bacteria can later spread their resistance to human beings and cause infections which would make the treatment difficult $[29,30]$. To measure the burden and trends of drug resistance pattern in NTS, continuous surveillance and antibiotic susceptibility testing are essential to be performed in different geographical regions throughout the country [31].

\section{CONCLUSION}

Non-typhoidal salmonellosis is a major problem among immunocompromised patients. It is also the most common enteric pathogen isolated from Manipal, Karnataka. In the present study, PCR-based techniques with genus-specific primers corresponding to invA gene appeared to be rapid, sensitive, and precise. Detection of invA gene by PCR throws light on its invasive nature. $89.3 \%$ of the patients infected by NTS with invA gene had a fever along with diarrhea.
Thus, the invA gene proved to be a significant marker for bloodstream invasion and found in almost $90 \%$ of the patients suffering from nontyphoidal salmonellosis.

\section{REFERENCES}

1. Roman BS, Garrido V. Non-typhoidal Salmonellosis. Mol Vaccines 2013;1:329-42.

2. Nielsen LR. Review of pathogenesis and diagnostic methods of immediate relevance for epidemiology and control of Salmonella dublin in cattle. Vet Microbiol 2013;162(1):1-9.

3. Elizabeth LH. Nontyphoidal salmonellosis. Food Saf 2001;32:263-9.

4. Pires SM, de Knegt Tine Hald L. Estimation of the relative contribution of different food and animal sources to human Salmonella infections in the European union. EFSA Support Publ Eur Food Saf Authority 2011;8(8):80-184. Available from: http://www.efsa.europa.eu/en/ supporting/pub/184e.htm. [Last cited on 2015 Nov 08].

5. Feasey NA, Dougan G, Kingsley RA, Heyderman RS, Gordon MA. Invasive non-typhoidal Salmonella disease: An emerging and neglected tropical disease in Africa. Lancet 2012;379(9835):2489-99.

6. Jones TF, Ingram LA, Cieslak PR, Vugia DJ, Tobin-D'Angelo M, Hurd S, et al. Salmonellosis outcomes differ substantially by serotype. J Infect Dis 2008;198(1):109-14.

7. Kingsley RA, Msefula CL, Thomson NR, Kariuki S, Holt KE, Gordon MA, et al. Epidemic multiple drug resistant Salmonella typhimurium causing invasive disease in sub-Saharan Africa have a distinct genotype. Genome Res 2009;19(12):2279-87.

8. Gordon MA, Banda HT, Gondwe M, Gordon SB, Boeree MJ, Walsh AL, et al. Non-typhoidal Salmonella bacteraemia among HIVinfected Malawian adults: High mortality and frequent recrudescence. AIDS 2002;16(12):1633-41.

9. Graham SM, Walsh AL, Molyneux EM, Phiri AJ, Molyneux ME. Clinical presentation of non-typhoidal Salmonella bacteraemia in Malawian children. Trans R Soc Trop Med Hyg 2000;94(3):310-4.

10. Mir IA, Wani SA, Hussain I, Qureshi SD, Bhat MA, Nishikawa Y. Molecular epidemiology and in vitro antimicrobial susceptibility of Salmonella isolated from poultry in Kashmir. Rev Sci Tech 2010;29(3):677-86.

11. Centers for Disease Control and Prevention. Guidelines for Specimen Collection, Instructions for Collecting Stool Specimens. CDC; 2015. Available from: http://www.cdc.gov/foodsafety/outbreaks/investigating outbreaks/specimencollection.html. [Last cited on 2015 Aug 12].

12. Winn WC Jr, Allen SD, Janda WM, Koneman E, Procop G, Schreckenberger PC, et al. Koneman's Colour Atlas and Textbook of Diagnostic Microbiology. $6^{\text {th }}$ ed. Philadelphia, PA: Lippincott; 2006. p. 93-107.

13. Clinical and Laboratory Standards Institute CLSI. Performance Standards for Antimicrobial Susceptibility Testing, CLSI Supplement M100S. 26 $6^{\text {th }}$ ed. Wayne, PA: Clinical and Laboratory Standards Institute; 2016. Available from: https://www.clsi.org/standards/micro/ sub-ast. [Last cited on 2017 Mar 12].

14. de Medici D, Croci L, Delibato E, Di Pasquale S, Filetici E, Toti L. Evaluation of DNA extraction methods for use in combination with SYBR green I real-time PCR to detect Salmonella enterica serotype enteritidis in poultry. Appl Environ Microbiol 2003;69(6):3456-61.

15. Karmi M. Detection of virulence gene (inva) in Salmonella isolated from meat and poultry products. Int J Genet 2013;3(2):7-12

16. Hacker J, Kaper JB. Pathogenicity islands and the evolution of microbes. Annu Rev Microbiol 2000;54:641-79.

17. Dione MM, Ikumapayi U, Saha D, Mohammed NI, Adegbola RA, Geerts S, et al. Antimicrobial resistance and virulence genes of nontyphoidal Salmonella isolates in the Gambia and Senegal. J Infect Dev Ctries 2011:5(11):765-75.

18. Ohud M, Eman MH, Hayam SA. Detection of Salmonella strains in clinical samples from Saudi Arabia by invA and hilA polymerase chain reaction (PCR)-based assays. Afr J Microbiol Res 2012;6:5410-6.

19. de Oliveira SD, Rosane RC, Geovana BM, Marisa IR, Wageck CC, Adriano B. Detection of virulence genes in Salmonella enteritidis isolated from different sources. Braz J Microbiol 2003;34 Suppl 1:123-4. Available from: http://www.scielo.br/scielo. php?script $=$ sci_arttext\&pid $=$ S $151783822003000500042 \& \operatorname{lng}=$ en. [Last cited on 2017 May 24]

20. Saheli TZ, Mahzounieh M, Saeedzadeh A. Detection of InvA gene in isolated Salmonella from broilers by PCR method. Int J Poult Sci 2005;4:557-9.

21. Voetsch AC, Van Gilder TJ, Angulo FJ, Farley MM, Shallow S, Marcus R, et al. FoodNet estimate of the burden of illness caused by 
nontyphoidal Salmonella infections in the United States. Clin Infect Dis 2004;38 Suppl 3:S127-34.

22. Gordon MA. Salmonella infections in immunocompromised adults. J Infect 2008;56(6):413-22.

23. Taneja N, Appannanavar SB, Kumar A, Varma G, Kumar Y, Mohan B, et al. Serotype profile and molecular characterization of antimicrobial resistance in non-typhoidal Salmonella isolated from gastroenteritis cases over nine years. J Med Microbiol 2014;63:66-73

24. Dhanoa A, Fatt QK. Non-typhoidal Salmonella bacteraemia: Epidemiology, clinical characteristics and its' association with severe immunosuppression. Ann Clin Microbiol Antimicrob 2009;8:15.

25. Frasson I, Bettanello S, De Canale E, Richter SN, Palù G. Serotype epidemiology and multidrug resistance patterns of Salmonella enterica infecting humans in Italy. Gut Pathog 2016;8:26.

26. Kariuki S, Revathi G, Kariuki N, Kiiru J, Mwituria J, Muyodi J, et al. Invasive multidrug-resistant non-typhoidal Salmonella infections in Africa: Zoonotic or anthroponotic transmission? J Med Microbiol 2006;55:585-9. Available from: http://www.jmm.microbiologyresearch. org/content/journal/jmm/10.1099/jmm.0.46375-0. [Last cited on 2015 Nov 15]
27. Menezes GA, Khan MA, Harish BN, Parija SC, Goessens W, Vidyalakshmi K, et al. Molecular characterization of antimicrobial resistance in non-typhoidal salmonellae associated with systemic manifestations from India. J Med Microbiol 2010;59:1477-83.

28. Centers for Disease Control and Prevention. Salmonella Heidelberg Infections Linked to Foster Farms Brand Chicken, Multistate Outbreak of Multidrug-Resistant Salmonella Heidelberg Infections Linked to Foster Farms Brand Chicken (Final Update). Available from: https:// www.cdc.gov/salmonella/heidelberg-10-13/advice-consumers.html. [Last updated on 2014 Jul 31; Last cited on 2017 Jun 20].

29. Sandt CH, Fedorka-Cray PJ, Tewari D, Ostroff S, Joyce K, M'ikanatha NM. A comparison of non-typhoidal Salmonella from humans and food animals using pulsed-field gel electrophoresis and antimicrobial susceptibility patterns. PLoS One 2013;8(10):e77836.

30. Mwambete KD, Stephen WS. Innovare academic sciences antimicrobial resistance profiles of bacteria isolated from chicken droppings in dar Es Salaam. Int J Pharm Pharm Sci 2015;7:7-10.

31. Arora D, Gupta P, Gill G, Chawla R, Singla R. Changing trends in the antibiograms of Salmonella isolates in Northern Area of Punjab. Int J Pharm Pharm Sci 2010;2:3-5. 